\title{
TĚŽBA NEROSTNÝCH SUROVIN V ČR JAKO JEDEN Z FAKTORŮ REGIONÁLNÍHO ROZVOJE
}

\section{MINING IN THE CZECH REPUBLIC AS ONE OF THE FACTORS OF} REGIONAL DEVELOPMENT

\author{
DOC. RNDr. IRENA SMOLOVÁ, PH.D. ${ }^{1}$ \\ Mgr. Martin SVOBODA ${ }^{2}$ \\ ${ }^{1}$ Katedra geografie ${ }^{1}$ Department of Geography \\ ${ }^{2}$ Katedra rozvojových studii $\quad{ }^{2}$ Department of Development Studies \\ Přrirodovédecká fakulta Faculty of Science \\ Univerzita Palackého v Olomouci $\mid$ Palacký University in Olomouc \\ $\bigotimes$ tř. 17. listopadu 12, 77146 Olomouc, Czech Republic \\ E-mail: irena.smolova@upol.cz,martin.svoboda@upol.cz
}

\begin{abstract}
Anotace
Jedním z faktori ovlivňujicích regionálni rozvoj je přirodni potenciál území a jeho využivání. Př́spěvek se věnuje problematice přijmů obcí souvisejicich s těžbou nerostných surovin, kdy jedním z hlavním kompenzačnich nástrojủ státu voblasti těžby nerostných surovin jsou environmentální poplatky (poplatky za využiváni přirodnich zdrojů). Ekonomický efekt pro obce tvoři zejména přijmová položka obecního rozpočtu, která je stanovena horním zákonem (úhrady za vydobytý nerost a úhrady $z$ dobývacího prostoru), dále př́jmy plynouci do rozpočtu obce jako daňové výnosy v mistě sidla těžebni společnosti a di̊ležitým zdrojem jsou i mimorozpočtové příjmy obcí, pomoc při údržbě komunikaci či finanční spoluúčast na projektech podporujících rozvoj regionu. Legislativa i přistup obci k těžbě surovin se od roku 1989 výrazně proměnil, což je dokumentováno na vybraných př́kladech.
\end{abstract}

\section{Klíčová slova}

těžba surovin, úhrady z těžby surovin, těžba uranu v $\check{C} R$

\section{Annotation}

One of the factors influencing regional development is the natural potential and its use of the area. The paper deals with the issue of municipal revenues associated with the mining and quarrying where one of the main instruments of the state compensation in the mining sector are environmental fees (fees for the use of natural resources). The economic effect of the municipalities is mainly revenue into municipal budget, which is set by the Mining Act (payments for extracted mineral and taxes from the mining spaces), as well as revenue flowing into the municipal budget as tax yields at the domicile of the mining company and important sources are also non-budgetary income of municipalities, help with road maintenance or financial participation in projects supporting the development of the region. Legislation and communities approach to raw materials extraction since 1989 has changed, which is documented on selected examples.

Key words

mining, payments from mining, uranium mining in the Czech Republic

JEL classification: $R 11, R 14, R 51$ 


\section{1. Úvod}

Evropa a zejména západní a střední Evropa je zatěžována hornickou činností již několik tisíciletí. Těžba surovin znamenala prosperitu i problémy pro regiony, které mají surovinový potenciál. $\mathrm{V}$ průběhu doby se př́stupy $\mathrm{k}$ těžbě surovin měnily a stejně tak i ekonomický efekt pro region. Vliv hornictví na rozvoj území v českých zemích začal mít větší význam od období středověku. V této době začaly být vydávány první kodexy, které upravovaly práva a povinnosti těžařu. Horní právo se výrazně kodifikovalo v období po roce 1750 , v polovině 19. století bylo horní právo zpracováno tak, že základní zákony byly platné až do roku 1957, kdy po nabytí účinnosti nového horního zákona (roku 1957) převzal kontrolu nad těžbou stát, v období socialismu úplnou, od roku 1990 postupně ekonomicko - ekologickou.

\section{Cíle a metody}

Cílem příspěvku je dokumentovat ekonomický efekt těžby nerostných surovin pro dotčená území v ČR v období po roce 1990 v souvislosti se změnou legislativy a př́stupu k environmentálním otázkám. Pozornost je věnována nástrojům, které stát využívá při kompenzaci dopadů těžby nerostných surovin, a na konkrétních př́kladech je srovnán dopad těchto nástrojů na kvalitu života. Pro účel srovnání je zvolena jediná lokalita současné těžby uranové rudy na území ČR Dolní Rožínka. Hlavními metodami využitými při zpracování př́spěvku jsou analýza legislativních nástrojů a vlastní šetření, výzkum vybavenosti v zájmovém regionu a analýzy rozpočtových př́ijmů obcí.

\section{Kompenzační nástroje státu - úhrady za dobývání nerostných surovin}

Hlavním kompenzačním nástrojem státu $\mathrm{v}$ oblasti těžby nerostných surovin jsou environmentální poplatky. Jak uvádí Samuelson (2007), poplatky jsou nástrojem regulace znečištování, jejichž sazba by se měla rovnat externím nákladům vznikajícím v důsledku znečištění. Došlo by tak k úplné internacionalizaci externalit, znečišt’ovatel by nesl ve svých (interních) nákladech výši externích nákladů. Environmentální poplatky lze definovat jako platby, které jsou upraveny zákony k ochraně životního prostředí a jsou tedy vždy specifické pro konkrétní př́iklad. Nelze používat výraz „poplatky“ samostatně, ale vždy plným názvem dle konkrétního zákona (např. poplatek za odebrané množství podzemní vody). V České republice je obecně přijímána klasifikace ekonomických nástrojů OECD, která vymezuje celkem 15 environmentálních poplatků. Tyto poplatky jsou logicky tříděny do tř́i kategorií: poplatky za znečištění či jiné poškozování (zatěžování) životního prostředí (1), poplatky za využívání prírodních zdrojů (2) a uživatelské poplatky (3). Do první kategorie jsou zařazeny např. poplatky za ukládání odpadů na skládky a poplatek za vypouštění odpadních vod do vod povrchových. Do kategorie uživatelských poplatků patří poplatky za spotřebu látek poškozujících ozónovou vrstvu. Oblast těžby surovin náleží do kategorie poplatků za využívání přírodních zdrojů, kde jsou zahrnuty úhrady, které musí platit subjekty zabývající se těžbou nerostných surovin. Jedná se o úhrady za dobývací prostor a úhrady za vydobytý nerost.

V rovině oficiální a zákonné př́ijmy obcí plynoucí ze stanovených odvodů reprezentují současnou podobu historického institutu, známého v českých zemích jako „urbura“, v anglosaských zemích jako „,royality“. Jedná se o poplatky, které jsou placeny vlastníkovi nerostného bohatství za to, že své vlastnictví (ložiska nerostů) poskytuje (propůjčuje) báňskému podnikateli a umožňuje mu přivlastnit si z ložiska vydobyté, popř́padě upravené, nerosty prodat a z tohoto podnikání mít zisk. Platby tohoto typu jsou známy ze všech zemí, kde probíhá těžba nerostů. V závislosti na historickém vývoji, právním systému a úloze a postavení báňského podnikání v hospodářství dané země, je definována konkrétní podoba těchto úhrad ve formě poplatků, daní či odvodů. Povinnost úhrady těchto poplatků je stanovena bud' horními zákony, nebo zvláštními zákony, které upravují pouze tuto problematiku. Metodika výpočtu se v jednotlivých zemích liší. V podstatě převažují dva základní systémy, tj. fixně stanovená suma za jednotku těžby nebo procento z ceny suroviny nebo dosažené tržby. Př́ijemcem těchto úhrad byl v minulosti panovník, který je používal obvykle k upevnění své moci a moci státu, v moderní době je př́jemcem obvykle stát. 
Do českého horního práva byly poplatky z těžby zavedeny novelou horního zákona zákonem č. 541/1991 Sb. (Úhrada je přesně vymezena § 32a Horního zákona.), s platností od 20. 12. 1991. K zavedení plateb došlo v období zvýšené kritiky vlivu dobývání na krajinu, občany a životní prostředí, bez zvážení nezastupitelné úlohy těžebního průmyslu pro rozvoj státu a bez analýzy příčin a důsledků kritizovaných negativních vlivů těžby. To se projevilo tím, že na rozdíl od celosvětových zvyklostí nebyly úhrady směrovány na stát, ale úhrady z plochy dobývacího prostoru (neboli z plochy těžaři státem udělené těžební licence) byly směrovány na obec a úhrady z vytěžených nerostů (neboli z podnikatelského využití vlastnictví státu) byly rozděleny mezi obce a stát rovným dílem.

Př́ijmy z těžby nerostných surovin, které byly pro obce i státní rozpočet do roku 1992 nulové, se počínaje rokem 1993 vybírají jako úhrady za dobývací prostor a úhrady za vydobyté nerosty (podle přechodného ustanovení byla zpětně stanovena povinnost zaplatit za rok 1991 a 1992 do 31. 3. 1993.). U nových dobývacích prostorů platby úhrad zahajuje organizace $\mathrm{v}$ kalendářním roce následujícím po roce, v němž byl dobývací prostor stanoven a platby úhrad končí zrušením dobývacího prostoru. Počínaje rokem 1993 (resp. 1991) byla těžební činnost zpoplatněna a př́ijemcem úhrad z dobývacích prostorů se staly příslušné obce, prŕjmy z vydobytých nerostů se dělí mezi obce a stát.

Zákonem stanovené úhrady z dobývacího prostoru jsou placeny těžební společností příslušnému báňskému úruadu, který následně převede příslušnou část do rozpočtu obce, na jejímž území se dobývací prostor nachází. Je-li dobývací prostor umístěn na území více obcí, rozdělí obvodní báňský úřad příjem podle poměru částí dobývacího prostoru na území jednotlivých obcí. V letech 1992 až 2005 byla roční úhrada $z$ dobývacího prostoru většího než 2 ha stanovena ve výši 10 tisíc Kč a násobila se $\mathrm{s}$ každým započatým $\mathrm{km}^{2}$, u dobývacích prostorů menších jak 2 ha činila roční úhrada paušálně 2 tisíce Kč. Nový možný odlišný pohled na úlohu úhrad z dobývacích prostorů přinesla Vláda ČR svým usnesením v prosinci 1999 k surovinové politice v oblasti nerostných surovin a jejich zdrojů, ve kterém uložila MŽP ČR úkol „Navrhnout nový systém plateb úhrad z dobývacích prostorů, tyto úhrady koncipovat jako ekonomický nástroj politiky ochrany životního prostředí a krajiny, tj. diferencovat je podle hodnoty dotčeného území, míry dopadu a charakteru prováděných prací“. MŽP ČR zpracovalo materiál, který byl schválen $\mathrm{v}$ jeho vedení, který předpokládal kategorizaci území na základě „koeficientu hodnoty územi““ a „kategorie zásahu či omezení funkčnosti území“ do čtyř základních kategorií ekologické újmy území. K jednotlivým základním kategoriím byly přiřazeny konkrétní výše úhrad za 1 ha plochy dobývacího prostoru ve výši 100 Kč pro nízkou, 300 Kč pro střední, 700 Kč pro vysokou a 1000 Kč pro velmi vysokou ekologickou újmu území. Jako podmínka pro efektivní uplatnění tohoto systému bylo předpokládáno umožnění změn ve vymezení dobývacích prostorů bez vlivu na změny těžebních práv (což současný horní zákon neumožňuje). K zásadní změně ve výpočtu úhrady z dobývacího prostoru však došlo až novelou horního zákona č. 386/2005 Sb., kdy bylo stanoveno, že úhrada se počínaje rokem 2006 platí v rozsahu 100 až 1000 Kč na každý (i započatý) hektar plochy dobývacího prostoru. Přitom konkrétní výše platby má vycházet ze stupně ochrany životního prostředí dotčeného území, charakteru činnosti prováděné v dobývacím prostoru a jejím dopadu na životní prostředí. Výši úhrady mělo stanovit nařízení vlády, které však do současné doby vydáno nebylo, což s sebou přineslo řadu komplikací. Vývoj výše úhrad od roku 1993 ukazuje, že se výše úhrad z plochy dobývacích prostorů logicky snižuje, což zcela koresponduje s poklesem počtu dobývacích prostorů $v$ jednotlivých letech. Pokles výše úhrad v roce 2006 je způsoben změnou metodiky výpočtu. S ohledem na skutečnost, že Vláda ČR nevydala nařízení, ve kterém by se stanovily konkrétní výše úhrad $\mathrm{v}$ jednotlivých ochranných zónách a typech krajiny, zejména ve zvláště chráněných územích, podobně jako nebyly stanoveny výše úhrad podle charakteru hornické činnosti a jejím dopadu na životní prostředí, řídila se výše plateb z dobývacího prostoru stavem legislativní nouze a většina těžebních společností vypočítala úhradu z dobývacího prostoru podle spodní (nejnižší) hranice státem stanoveného rozpětí úhrady. Zatímco v roce 1993 bylo na území ČR stanovených 1088 DP a výše úhrady dosáhla téměř 26 mil. Kč, v roce 2010 dosáhla výše úhrady za dobývací prostory obcím již jen 14 mil. Kč, tj. v průměru 13 tis. Kč na jednu obec. Na straně druhé se však pro obce výrazně zvýšily platby za vydobyté nerosty. Je však nutné poznamenat, že zavedení plateb úhrad z plochy dobývacího prostoru přimělo většinu těžebních společností k redukci dobývacích prostorů. 
Jednalo se zejména o dobývací prostory energetických surovin (lignitu a černého a hnědého uhlí), kdy $\mathrm{k}$ rušení dobývacích prostorů docházelo v souladu se schválenými útlumovými programy.

Ekonomicky zajímavější je roční úhrada z vydobytých nerostů, která se vypočítává jako procentuální podíl z celkové tržby za vydobyté nerostné suroviny oceněné tržní cenou v období, za které se výpočet provádí (nejvýše však $10 \%$ ). Úhrada za vydobytý nerost je poplatek, který obcím kompenzuje újmy vyplývající z probíhající těžby nerostných surovin na jejich katastru. Do výpočtu úhrady vstupuje několik proměnných, což má za následek rozdílné výše úhrad pro jednotlivé těžené nerosty. Výše úhrady může být maximálně $10 \%$ z tržní ceny nerostu. Rozhodná je průměrná tržní cena v roce, ve kterém byl vyhrazený nerost vydobyt. Procentuální výše tržní ceny je stanovena vyhláškou č. 617/1992 Sb. Maximální výše, tedy 10 \% z tržní ceny, je pouze u 3 nerostů (rudy, technicky využitelné krystaly nerostů a drahé kameny, vysokoprocentní vápenec). Pro ropu a hořlavý zemní plyn je sazba $0,5 \%$ a pro radioaktivní suroviny, kam řadíme uranovou rudu, je sazba pouze 0,3 $\%$, což je nejméně ze všech vyhrazených nerostů. Dalšími proměnnými, které výrazně ovlivňují výše úhrad, jsou náklady na dobývání nerostu a celkové náklady organizace na zhotovení výrobku (vyhláška č. 617/1992 Sb.). Celková výše úhrady je rozdělena mezi obec a stát. V období let 1992 2000 byly př́jmy z úhrad děleny mezi obec a stát rovným dílem. Počínaje prosincem $2000^{1}$ jsou v souladu s novelou horního zákona zákonem č. 366/2000 Sb., př́ijmy z úhrad z vydobytých nerostů na výhradních ložiscích přerozdělovány mezi obce a stát ve prospěch obcí v poměru $75 \mathrm{ku} 25 \%$. Pro obce, na jejichž území probíhá těžba, se tak výrazně zvýšily př́ijmy z vydobytých nerostů. V ročním objemu dosáhl meziroční nárůst téměř 75 mil. Kč (z 228 mil Kč pro obce v roce 1999 na 302 mil Kč $\mathrm{v}$ roce 2001. Účty firmami placených úhrad vedou př́slušné báňské úřady, které finanční prostředky poukazují ve prospěch oprávněných př́iemců (obce a státní rozpočet). Ve výši úhrad se zatím v omezené míře promítá i faktor vlivu dobývání na sociálně ekonomickou situaci v regionech, byt' se prozatím uplatnil pouze $\mathrm{v}$ jediném prrípadě, a to při stanovení výše úhrady pro radioaktivní suroviny ( $0,3 \%$ - nejnižší stanovená výše), které jsou dobývány na jediném dole v Rožné a představují pro část území Českomoravské vrchoviny zatím obtížně nahraditelný zdroj pracovních příležitostí. Může se uplatnit také při rozhodování o žádostech o snížení nebo odpuštění úhrady.

\section{Obr.1: Vývoj výše úhrad za dobývací prostor a vydobyté nerosty v období let 1993 - 2010 (v tis. Kč)}

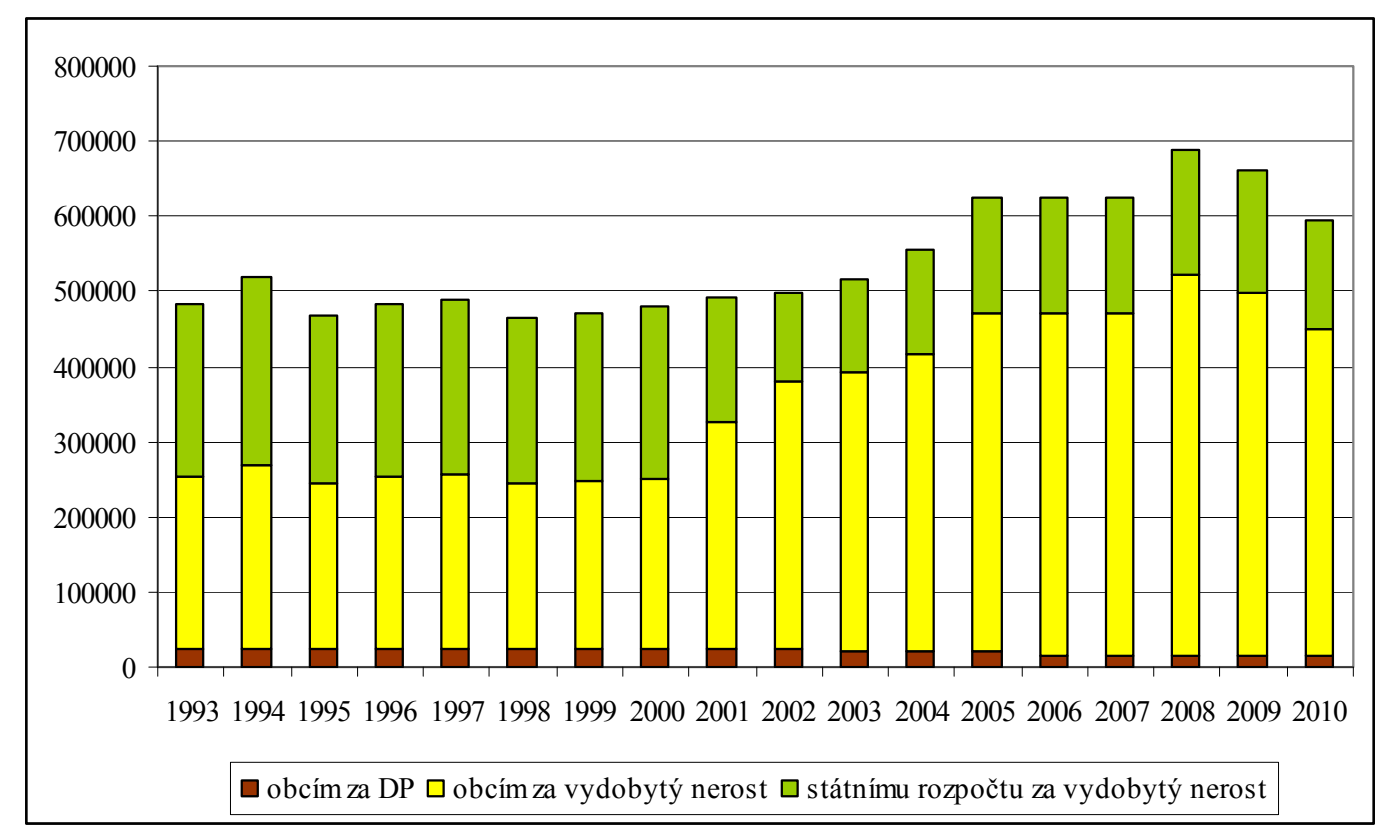

Zdroj: Hornické ročenky, Ministerstvo životniho prostředí, vlastní výpočty

Vývoj výše úhrad z vydobytých nerostů v letech 1993 - 2010 dokumentuje obr. č. 1, ze které vyplývá, že se výše úhrad z vydobytých nerostů celkově zvyšuje a výrazný je zejména nárůst 
v kategorii př́jmů obcí, což zcela koresponduje s vývojem legislativy a zásadní změnou v systému přerozdělování v roce 2000. Rostoucí trend je přitom, i přes celkový útlum těžby nerostných surovin ve srovnání se stavem v roce 1993, způsoben zejména růstem cen těžených nerostných surovin. Výrazný je nárůst po roce 2002, který v sobě odráží i ekonomicky zajímavou rostoucí těžbu stavebních surovin. Legislativní změna z roku 2005 by se při stabilním objemu těžby i stabilních cenách projevila poklesem výše úhrad za vydobyté nerosty. Celkový meziroční nárůst (2005/2006) je však zásadně ovlivněn vysokým nárůstem úhrady za těžbu ropy a zemního plynu způsobenou jak nárůstem těžby, tak zejména nárůstem cen a tím i tržeb.

Tab. 1: Vývoj úhrad z dobývacího prostoru a z vydobytého nerostu v období let 2004 - 2010

\begin{tabular}{|l|c|c|c|c|c|c|c|}
\hline \multicolumn{8}{|c|}{ Úhrady z dobývacího prostoru } \\
\hline & $\mathbf{2 0 0 4}$ & $\mathbf{2 0 0 5}$ & $\mathbf{2 0 0 6}$ & $\mathbf{2 0 0 7}$ & $\mathbf{2 0 0 8}$ & $\mathbf{2 0 0 9}$ & $\mathbf{2 0 1 0}$ \\
\hline celkem v tis. Kč & 21511 & 21977 & 16178 & 15496 & 15127 & 14925 & 14032 \\
\hline \multicolumn{8}{|c|}{ Úhrady z vydobytého nerostu } \\
\hline & $\mathbf{2 0 0 4}$ & $\mathbf{2 0 0 5}$ & $\mathbf{2 0 0 6}$ & $\mathbf{2 0 0 7}$ & $\mathbf{2 0 0 8}$ & $\mathbf{2 0 0 9}$ & $\mathbf{2 0 1 0}$ \\
\hline celkem v tis. Kč & 532750 & 602509 & 608614 & 657813 & 674399 & 633570 & 579481 \\
\hline
\end{tabular}

Zdroj: Statistická ročenka životního prostředi České republiky 2009, Hornická ročenka, vlastní výpočty

V roce 2010 byla obcím poskytnuta úhrada z plochy dobývacího prostoru v celkové výši 14 mil. Kč a úhrada z vydobytých vyhrazených nerostů dosáhla částky 435 mil. Kč pro obce a 145 mil. Kč do státního rozpočtu. Na celkové výši úhrady za vydobyté nerosty se podílí 44,8 \% hnědé uhlí, 17,7\% černé uhlí, 19,9\% ropa a zemní plyn, 6,0 \% vápence, 4,4 \% stavební kámen, $2,0 \%$ štěrkopísky a 1,7\% jíly. Ostatní suroviny se podílí méně než jedním procentem. Díky nerovnoměrnému prúrodnímu potenciálu jsou př́ijmy výrazně diferencovány podle regionů. Z krajů má nejvyšší př́ijmy plynoucí z horního zákona Moravskoslezský a Ústecký kraj. Významné mohou být př́ijmy pro rozvoj obce a širšího území, zvláště pak v marginálních územích (Smolová, Szczyrba, 1998).

Využití př́imů z těžby nerostných surovin je diferencované na úrovni obcí a státu (státního rozpočtu). Zatímco obcím není zákonem stanoven účel, jak prostředky využívat, a je pouze na rozhodnutí dané obce, jak př́ijmy z úhrad za vydobyté nerosty využije. Prostředky, které z těžební činnosti plynou do státního rozpočtu, jsou ze zákona určeny pouze na nápravu škod na životním prostředí, které vznikly v souvislosti s dobýváním výhradních i nevyhrazených ložisek. K přesnější specifikaci byla príijata Usnesení Vlády ČR. Poslední platné přiděluje počínaje rokem 2002 polovinu úhrad MPO ČR na účelové nápravy škod na životním prostředí (rozdělovány jsou vybraným těžebním organizacím ve formě účelových dotací). Takto se část úhrad vrací k jejich plátcům, kteří je vynakládají na území dosud nezrušených DP, tj. na území obcí, které pobírají úhrady z DP a v některých případech i úhrady z vydobytých nerostů. Druhá polovina je přidělena MŽP ČR na zajišt'ování nebo likvidaci starých důlních děl, realizované cestou veřejných zakázek.

V kategorií obcí s nejvyššími příjmy z vydobytých nerostů jsou obce voblasti těžby uranové rudy, černého a hnědého uhlí. Roční př́ijmy vyšší než 10 mil. korun mají např́íklad obce Most, Horní Jiřetín nebo Malé Březno v oblasti Podkrušnohoří. V sumárním vyjádření za období posledních sedmi let tak např́iklad město Most získalo do rozpočtu více než 150 mil. korun. Ještě výraznější je to pak u menších obcí s celkově menším rozpočtem, kde úhrady plynoucí z těžební činnosti mohou tvořit $\mathrm{i}$ více než 80 \% rozpočtu obce (např. obce Horní Jiřetín, Strupčice nebo Malé Březno). 


\section{Těžba uranové rudy v regionu Rožná a ekonomický efekt pro region}

Odštěpný závod GEAM Dolní Rožínka (déle jen závod) už 55 let provádí těžbu uranové rudy v oblasti Dolní Rožínky ( $8 \mathrm{~km}$ jižně od Bystřice nad Pernštejnem). Př́nos závodu pro blízké okolí není pouze v zaměstnanosti, ale ovlivňuje i řadu dalších aktivit. V 60. letech 20 . století, v době prudkého rozmachu uranového hornictví, začaly vznikat nové budovy a zařízení. Podnik v těchto letech evidoval přes 4000 zaměstnanců, což s sebou neslo velké požadavky na investice do bydlení a služeb. Masivní bytová výstavba probíhala zpravidla v lokalitách umožňující dojiždění do zaměstnání. Zprvu se stavěla dřevěná sídliště a ubytovny a to pokud možno v místech uranového ložiska. V Dolní Rožínce vyrostlo nové hornické sídliště, kulturní dům, zdravotní středisko, prodejny zboží, závodní jídelna a část autobusového nádraží, to vše za 20 miliónů korun. V Bystřici nad Pernštejnem bylo v letech 1958 - 1966 budováno sídliště I a po roce 1964 se začalo s výstavbou sídliště II. Celkem bylo postaveno 1546 bytových jednotek. Bývalý podnik Uranových dolů se rovněž podílel na stavbě obchodní sítě pro nová sídliště. Šlo o obvyklou situaci, kdy extenzivní rozvoj průmyslu doprovázela výstavba potřebných zařízení občanské vybavenosti sídel (Szczyrba, 2005). V Bystřici nad Pernštejnem s přispěním bývalého podniku Uranové doly vznikly další stavby občanské vybavenosti: mateřská škola, základní škola, závodní jídelna, kulturní dům, zdravotní středisko. Celkem podnik v těchto letech proinvestoval téměř 200 miliónů korun. Nová sídliště a další zařízení občanské vybavenosti byla budována i v Tišnově a v Novém Městě na Moravě. Všechny tyto investiční akce byly z části nebo celé financovány bývalým podnikem Uranové doly, dnes známém jako Odštěpný závod GEAM Dolní Rožínka. Tímto způsobem se podnik podílel na zlepšování kvality života obyvatel v okolí uranových dolů, jelikož až do roku 1988 neexistovala právní úprava, která by nařizovala podniku platit obcím jakékoliv poplatky. S prijietím horního zákona v roce 1988 nastala povinnost podniku odvádět obcím a státu úhrady za dobývací prostor a úhrady za vydobytého nerostu. Před redukcí měl dobývací prostor Rožná rozlohu téměř $12 \mathrm{~km}^{2}$ a rozkládal se katastrálním území obcí Bukov, Milasín, Rožná, Dolní Rožínka, Rodkov, Zvole, Blažkov, Horní Rozsíčka, Vojetín, Blažejovice a Horní Rožínka. Rozhodnutím Obvodního báňského úřadu Liberec byl v roce 1996 dobývací prostor Rožná zmenšen na současnou rozlohu 876,4054 ha. Nachází se na katastrálním území obcí Horní Rozsíčka, Bukov, Milasín, Rodkov, Horní Rožínka, Blažkov, Dolní Rožínka a Rožná (Hájek a kol. 2007). Tyto obce se dělí ročně o 87700 Kč, které podnik odvádí na účet př́slušného báňského úřadu jako úhradu za dobývací prostor. Největší podíl získávají obce Dolní Rožínka (30 \%), Bukov ( $24 \%$ ) a Rožná (22 \%), dohromady přibližně 76 \% z celkové částky.

Tab. 2: Úhrada za dobývací prostor Rožná v letech 2005 - 2011

\begin{tabular}{|l|l|r|}
\hline \multicolumn{3}{|c|}{ Dobývací prostor Rožná } \\
\hline období & Plocha & \multicolumn{1}{|c|}{ Úhrada } \\
\hline do roku 2005 & $8,764054 \mathrm{~km}^{2}$ & $90000 \mathrm{Kč}$ \\
\hline $2006-2011$ & $8,764054 \mathrm{~km}^{2}$ & $87700 \mathrm{Kč}$ \\
\hline
\end{tabular}

Úhrada za vydobytý nerost představuje o řád vyšší platby pro obce a i stát, ale týká se pouze obcí, na jejichž katastru se aktuálně dobývá uranová ruda. Těžba uranové rudy neprobíhá v celém území vymezeného dobývacího prostoru, ale pouze v určitých sektorech. Při hlubinné těžbě je zapotřebí promítnout hranice dobývaných sektorů $\mathrm{v}$ podzemí na zemský povrch, abychom zjistili, na kterých katastrech probíhá těžba. Momentálně se uranová ruda těží na katastrech obcí Bukov a Dolní Rožínka. Objem získaných prostředků se každý rok mění a to hlavně z důvodu přesunu těžby uranové rudy v rámci dobývacího prostoru a nestálé ceny uranové rudy na světových trzích. 
Tab. 3 Struktura rozpočtı̊ obcí z pohledu poplatků spojených s těžbou uranové rudy

\begin{tabular}{|c|c|c|c|c|}
\hline Obec & Př́ijmy rozpočtu obce & 2009 & 2010 & 2011 \\
\hline \multirow[t]{3}{*}{ Dolní Rožínka } & př́ijmy celkem & 18455130 & 11572480 & 12983240 \\
\hline & úhrady celkem & 505840 & 419760 & 211530 \\
\hline & úhrady podíl & $2,82 \%$ & $2,24 \%$ & $1,26 \%$ \\
\hline \multirow[t]{3}{*}{ Bukov } & př́ímy celkem & 11489430 & 14042370 & 16272490 \\
\hline & úhrady celkem & 435430 & 580680 & 835660 \\
\hline & úhrady podíl & $6,84 \%$ & $5,60 \%$ & $4,83 \%$ \\
\hline
\end{tabular}

Zdroj: http://www.rozpocetobce.cz; vlastni výpocty

Obec Dolní Rožínka se musí ve svém rozpočtu vypořádat s každoročním úbytkem objemu získaných prostředků z úhrad. Naopak obec Bukov eviduje zvýšení objemu získaných prostředků a to dokonce mezi lety 2009 a 2011 o více než $40 \%$. Podíl úhrad na celkových př́jmech obce ale mají klesající tendenci. Jak je patrné z Tab. 3 samotná výše získaných prostředků z úhrad nepokryje financování velkého projektu, ale lze realizovat menší projekty, nebo částečně financovat projekty větších rozměru a tím zlepšit život lidí v obci. Obec Bukov postavila víceúčelové hřiště, vyasfaltovala místní komunikace a zrekonstruovala kanalizaci. Obec Dolní Rožínka zrekonstruovala budovu obecního úřadu a rekonstrukcí rovněž prošlo zázemí fotbalového hřiště.

Mimo úhrady z dobývacího prostoru a vydobytého nerostu je nutné v souvislosti s těžbou uranové rudy zmínit daň z nemovitosti, kterou odvádí podnik obcím, na jejichž katastru se rozkládají povrchové areály. Nejvíce finančních prostředků z této daně získává obec Rožná. Částky se mohou pohybovat $\mathrm{v}$ řádech miliónů a jsou několikanásobně vyšší než celkový součet úhrad $\mathrm{z}$ dobývacího prostoru a vydobytého nerostu. Získané prostředky obec investuje převážně do infrastruktury (byl vybudován nový sportovní areál $\mathrm{s}$ tenisovými kurty, koupalištěm a dětským hřištěm, který slouží občanům obce i široké veřejnosti). Část peněž byla použita na výstavbu kanalizace a čistírny odpadních vod. Z konkrétních př́íkladů je patrné, že získané finanční prostředky jsou smysluplně využity na projekty, které přispívají k rozvoji dané obce a k zatraktivnění okolního prostředí. 
Obr.2a: Počty dojǐždějicích pracovníků do závodu GEAM Dolní Rožínka (stav k 31. 12. 2012) Ob. 2b. Dobývací prostor Rožná a lokalizace hlavních objektů závodu GEAM Dolní Rožínka ve vazbě na katastrálních území
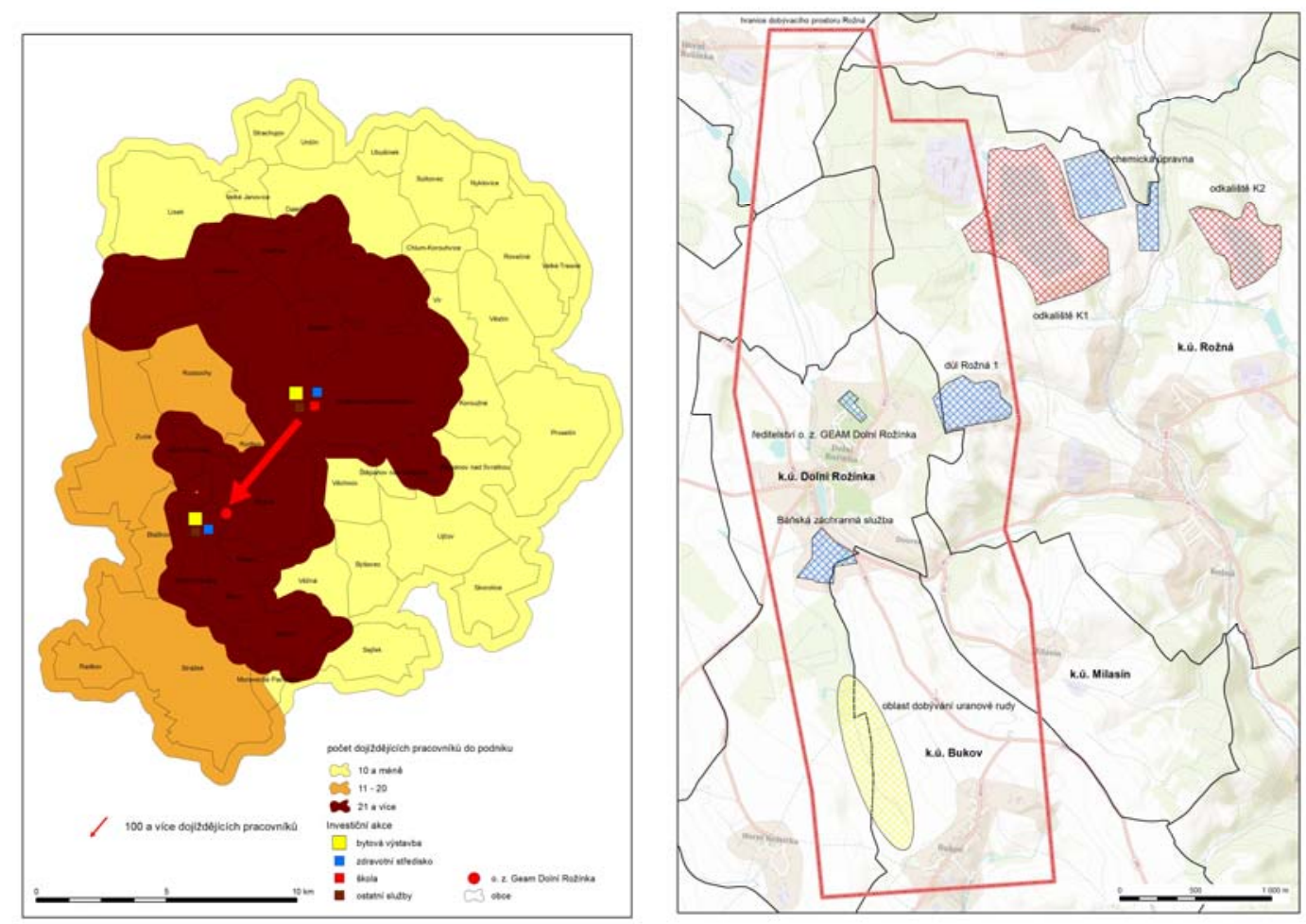

Zdroj: GEAM Dolní Rožínka, vlastní výpočty

Př́ńnos podniku pro obyvatele obce Dolní Rožínka lze dokumentovat i na frekvenci autobusových spojů, které směřují do obce. Podle jízdních řádů platných od 9. 12. 2012 je obec obsluhována celkem 10 autobusovými linkami. V pracovních dnech můžou obyvatelé obce a pracovníci podniku využít celkem 53 spojů, které obec spojují s okolními obcemi a městy. Tato frekvence spojů vychází z historické potřeby dopravit velké množství pracovníků do podniku. Počet pracovníků se ustálil na hodnotě 1000, čímž klesl počet pracovníků za posledních 10 let o $75 \%$. V obecné rovině klesla intenzita dojížd'ky veřejnou dopravou v celé ČR (Szczyrba, Toušek, 2004). Lidé preferují automobilovou dopravu, jelikož je rychlejší a flexibilnější. Autobusové spoje už nejsou tolik využívané a jejich obsazenost neodpovídá množství vypravených spojů. Srovnáním stejně velkých obcí zjistíme, že počet linek, které obsluhují Dolní Rožínku, je opravdu nadprůměrný. Například do obce Zvole, která je vzdálená pouze 4 km od Dolní Rožínky, zajíždí v pracovní dny 4 linky, do obce Dalečín na Bystřicku také 4 linky a do obce Štěpánov nad Svratkou 6 linek. Nicméně pro obyvatele obce Dolní Rožínky je to určitý komfort, který jim byl ponechán jako relikt dřívější doby.

\section{Závěr}

Ekonomický efekt pro obce tvoří zejména příjmová položka obecního rozpočtu, která je stanovena horním zákonem (úhrady za vydobytý nerost a úhrady z dobývacího prostoru), dále př́imy plynoucí do rozpočtu obce jako daňové výnosy v místě sídla těžební společnosti a důležitým zdrojem jsou i mimorozpočtové př́ijmy obcí, pomoc při údržbě komunikací či finanční spoluúčast na projektech podporujících rozvoj regionu. Legislativa i přistup obcí k těžbě surovin se od roku 1989 výrazně proměnil stejně jako využití př́imů z těžby surovin, které je diferencované na úrovni obcí a státu (státního rozpočtu). Zatímco obcím není zákonem stanoven účel, jak prostředky využívat, a je pouze na rozhodnutí dané obce, jak prŕjimy z úhrad za vydobyté nerosty využije. Prostředky, které z těžební činnosti plynou do státního rozpočtu, jsou ze zákona určeny pouze na nápravu škod na životním prostředí, které vznikly v souvislosti s dobýváním výhradních i nevyhrazených ložisek. V současné době se význam těžby nerostných surovin přesouvá z oblasti veřejného zájmu do polohy zájmu 
soukromých těžebních společností, které se snaží ekonomicky zhodnotit surovinový potenciál území. Tím ale také dochází $\mathrm{k}$ řadě průvodních střetů zájmů - obce, občanská sdružení, versus těžařské společnosti. Nicméně „těžařská lobby“ sehrává významnou úlohu v regionálním rozvoji. Obzvlášt' v územích se slabě rozvinutou hospodářskou základnou je prítomnost těžařských firem vnímána vesměs pozitivně, a to mnohdy navzdory krajinným rizikům a zátěžím, které z dobývací činnosti plynou. Ekonomický efekt pro obce tvoří zejména př́ijmová položka obecního rozpočtu, která je stanovena horním zákonem, dále příjmy plynoucí do rozpočtu obce jako daňové výnosy v místě sídla těžební společnosti a důležitým zdrojem jsou i na mimorozpočtové př́imy obcí, pomoc při údržbě komunikací či finanční spoluúčast na projektech podporujících rozvoj regionu. Obce jsou ekonomicky motivovány již při samotném procesu schvalování povolení k hornické činnosti. Př́íladem z nedávné doby je nabídka obcím na Vysočině, kde má zájem těžit uran australská společnost Uran Limited. Dle sdělení generální ředitelky společnosti byla obcím nabídnuta za každé povolení průzkumu částka 800 tis. korun ročně. Další neoficiální zdroje pak plynou zastupitelům, kteří o povolení hornické činnosti rozhodují.

\section{Literatura}

[1] HÁJEK, A. Geologická charakteristika rudního pole Rožná - Olší. Minerál, 2001, roč. IX., č.2, s. $118-124$.

[2] HÁJEK, A. a kol. 50. výroči zahájení těžby uranu na ložisku Rožná. Dolní Rožínka: GEAM, 2007, $60 \mathrm{~s}$.

[3] HÁJEK, A., PECH, E. Od zahájení těžby uranu na ložisku Rožná uplynulo 50. let. Uhlí-rudygeologický průzkum, 2007, 49, č. 10, Praha: Zaměstnavatelský svaz důlního a naftového průmyslu, s. 4- 11.

[4] LEPKA, F. Český uran 1945- 2002: neznámé hospodářrsé a politické souvislosti. Liberec: Knihy $555,2003,101 \mathrm{~s}$.

[5] MAJER, J. Rudné hornictví v Čechách, na Moravě a ve Slezsku. Praha: Libri, 2004, $255 \mathrm{~s}$.

[6] SAMUELSON, P. Ekonomie. 18. vydání. Praha: NS Svoboda, 2007, 775 s.

[7] SMOLOVÁ, I. Těžba nerostných surovin na území ČR a její geografické aspekty. Olomouc: Univerzita Palackého v Olomouci, 2008, 195 s.

[8] SMOLOVÁ, I., SZCZYRBA, Z. Rozhodující socioekonomické faktory regionálního rozvoje marginálního území. In Miscellanea geographica, Universitatis Bohemiae Occidentalis 6. Plzeň : Západočeská univerzita, 1998. s.113-125.

[9] SVOBODA, M. Geografické aspekty těžby uranu v ČR se zaměrením na lokalitu Dolní Rožínka. [bakalářská práce]. Olomouc: PřF UP v Olomouci, 2009, 65 s.

[10] SZCZYRBA, Z. Maloobchod v České republice po roce 1989 - vývoj a trendy se zaměrením na geografickou organizaci. Olomouc : Univerzita Palackého, 2005. $126 \mathrm{~s}$.

[11] SZCZYRBA, Z., TOUŠEK, V. Vyjižd'ka a dojižd'ka do zaměstnání v České republice; změny v období transformace. In Jakubowicz, E., Raczyk, A.: (eds.) Przeksztatcenia regionalnych struktur funkcjonalno-przestrzennych VIII/2. Wrocław : Uniwersytet Wroclawski, 2004. s. 21-31.

[12] Usneseni Vlády ČR ze dne 15. 11. 1995 č. 645 k uvolněni finančnich prostředků z výnosủ úhrady za vydobyté vyhrazené nerosty prevádèné podle zákona č. 44/1988 Sb., o ochraně a využití nerostného bohatství (horni zákon), ve znění pozdějších předpisů, do státního rozpočtu.

[13] Usnesení Vlády ČR ze dne 12. 9. 2001 č. 906 k návrhu na zajištování a likvidaci starých důlních děl a jejich finančni zajištěni od roku 2002.

[14]Vyhláška Ministerstva hospodářství ČR č. 617/1992 Sb., o podrobnostech placeni úhrad $z$ dobývacích prostorů a $z$ vydobytých vyhrazených nerostů, která byla novelizována vyhláškou č. 426/2001 Sb.

[15]Vyhláška Ministerstva hospodářství ČR č. 63/2005 Sb., o podrobnostech placeni úhrad z dobývacich prostoru a $z$ vydobytých vyhrazených nerostü.

[16] Usnesení Vlády ČR ze dne 13. 12. 1999 č. 1311 k Surovinové politice voblasti nerostných surovin a jejich zdroju.

[17]Zákon č. 44/1988 Sb., o ochraně a využití nerostného bohatství (horní zákon), ve znění zákona č. 541/1991 Sb., zákona ČNR č.10/1993 Sb., 132/2000 Sb., 286/2000 Sb., 366/2000 Sb., 315/2001 Sb., 61/2002 Sb., 320/2002 Sb., 150/2003 Sb. a 3/2005 Sb. 